\begin{tabular}{c} 
International Journal of Engineering \& Technology, $7(4.36)(2018)$ 1139-1144 \\
International Journal of Engineering \& Technology \\
WPC \\
Website: www.sciencepubco.com/index.php/IJET \\
Research paper \\
\hline
\end{tabular}

\title{
Populus Tremula Plants with Reduced Expression of the 4- Coumarate-CoA Ligase Gene Demonstrate Defects of the Rhizogenesis
}

\author{
Yu.A.Kovalitskaya ${ }^{1}$, N.P.Kovalenko ${ }^{2}$, K.A.Shestibratov ${ }^{3 *}$ \\ ${ }^{1}$ Forest Biotechnology Group, Branch of Shemyakin and Ovchinnikov Institute of Bioorganic Chemistry, Russian Academy of Sciences, \\ Science Avenue 6, Pushchino 142290, Moscow Region, Russian Federation \\ ${ }^{2}$ Forest Biotechnology Group, Branch of Shemyakin and Ovchinnikov Institute of Bioorganic Chemistry, Russian Academy of Sciences, \\ Science Avenue 6, Pushchino 142290, Moscow Region, Russian Federation \\ ${ }^{3}$ Forest Biotechnology Group, Branch of Shemyakin and Ovchinnikov Institute of Bioorganic Chemistry, Russian Academy of Sciences, \\ Science Avenue 6, Pushchino 142290, Moscow Region, Russian Federation
}

\begin{abstract}
Changing expression of a single gene by introducing mutations or transformation often affects expression of other genes, which results in the modification of the plant phenotype. We have obtained aspen plants with reduced expression levels of 4CL gene (4-coumarate-CoA ligase). Change in qualitative composition and 11-23\% reduced lignin content were observed in the wood of the greenhouse plants. In the study of rhizogenesis in vitro it was found that the micro shoots of transgenic plants formed a greater number of adventive roots than in the control, 30\%. Studying the transgenic aspen plants grown in a greenhouse (3 months) and passed the semi-natural conditions trial (4 months) has revealed 5-10\% reduction in the lignin content, alteration of the phenotype - decrease in biometrical values (height and diameter of stem). Analysis of RNA from the plants grown under semi-natural conditions indicated changed expression levels of monolignol biosynthesis genes, 4CL, CCR1 (cinnamoyl-CoA reductase), CAD6 (cinnamyl-alcohol dehydrogenase), and CCoAOMT (caffeoyl-CoA O-methyltransferase). For the lines PtXVI4CL9a and PtXIII4CL2c grown under semi-natural conditions, weight of the root system was 1.5-2 fold reduced in the transgenic plants as compared to the control. The conductive: feeding root ratio was increased. Morphology of the root system was changed.
\end{abstract}

Keywords: Populus Tremula, 4-Coumarate-CoA Ligase, Gene, Rhizogenesis, plant

\section{Introduction}

Changes in a plant genome caused by mutations or introducing heterologous DNA may affect a number of characteristics, which could by directly or indirectly related to the changed target. These consequences are referred to as side effects. It is known that reducing expression levels of the gene of the 4-coumarate-CoA ligase (4CL), which is a key enzyme in the lignin biosynthesis, causes decrease in the lignin content and alteration of the wood chemical composition [1-3]. In addition to that, transgenic plants with reduced expression of this gene demonstrated phenotypic changes: wood browning, tillering and dwarf phenotype [4-10]. Leplé and coauthors [11] have discovered that reduced expression levels of the CCR gene (cinnamoyl-CoA reductase) in poplar is accompanied with a decrease in the lignin content, while xylem becomes orange-brown. The authors have demonstrated that the transgenic plants with reduced lignin content are lower than the control plants [11]. Plants with the reduced expression levels of the 4CL gene have morphological anomalies. In this case, altered formation of xylem vascular bundles [4,8,9,12-13]. However, other possible side effects and the reasons causing them were not yet studied.

Main parameters considered during assessing effect of some factor on a woody plant are height, trunk diameter, and the tree crown architecture, i.e., what characterizes its productivity [14]. Plant height directly depends on the genotype and environmental conditions (abiotic and biotic factors), and specificity of ontogenesis process [15]. The spatial configuration of the root system and its growth rate play an important role in providing the plant productivity. Rapidity of the vertical and horizontal growth of a root system provides the seed germination power, high competitiveness with neighbor plants, and availability of minerals (nitrogen, phosphorus, potassium, etc.). Architecture of a root system affects all of its functions by providing securing the plant in the soil, mineral and water metabolism, and interaction with soil biota. The spatial configuration is the most important feature of the plant root system. Its alteration affects architecture of the entire plant, growth rate, productivity, resistance to abiotic stresses, accessing nutrition, and ability to develop a response to a changing environment $[16,17]$.

We proposed that the reduced growth rate of aboveground organs in the plants with inhibited expression of the 4CL gene may be caused by the impairment of the root system development, which leads to disturbance of mineral metabolism in plants. This work aimed at examining the transgenic plant lines under semi-natural conditions, comparative analysis of the root system morphology and detecting deviations from the control. 


\section{Materials and Methods}

\subsection{Plant Material in Vitro}

Transgenic aspen lines PtXVI4CL9a and PtXIII4CL2c and the original genotype Pt Populus tremula $L$ were cultivated in vitro on the Woody Plant medium [18] containing vitamins MS [19] in glass jars. Passage duration was 4 weeks, $12 \mathrm{~h}$ day, $12 \mathrm{~h}$ night at $24^{\circ} \mathrm{C}$.

\subsection{Semi-Natural Conditions of Plant Cultivation}

1.5 months old plants of transgenic lines PtXVI4CL9a and PtXIII4CL2c, and control Pt plants adapted to the greenhouse conditions planted in 1.5 liter jars with peat:perlite (3:1 ratio) and cultured in a greenhouse until 3 month old. Cultivation conditions: $70-80 \%$ humidity at $24-26^{\circ} \mathrm{C}$. At the beginning of June the jars were transferred to an open ground and the plants were vegetated for four months (June to September) under climate conditions of the Moscow region. At least 30 plants were used for each line studied. Plants were set on the ground randomly in order to avoid variations due to edge effects and local conditions. At the beginning of October, seven months old plants that stopped growing were used for measuring biometric parameters, sampling wood for chemical analysis and assessing the root system morphology.

\subsection{Biometric Research}

Plant height was measured from root collar to apical bud after they stopped growing. The values are expressed in centimeters. Thirty plants groups were used in the analysis.

Plant diameter was measured at two perpendicular points at $2 \mathrm{~cm}$ form root collar. The results were expressed in millimeters, analyzed group comprised 30 plants.

\subsection{RNA Isolation}

Total plant RNA was extracted with using TRIzol ${ }^{\circledR}$ reagent (Invitrogen, USA) according to the manufacturer manual (http://www.invitrogen.com) from leaf tissue of six months old aspen plants, which were grown for three months in a greenhouse and for three months on an open ground under semi-natural conditions. Genome DNA was eliminated using TURBO DNase (Ambion, USA) according to the provided protocol. For the cDNA synthesis, $500 \mathrm{ng}$ of total RNA were used. RNA concentration was measured using a microvolume spectrophotometer Nanodrop 2000 (Thermo Scientific, USA). Synthesis of cDNA was carried out with RNaseH- reverse transcriptase M-MuLV (SibEnzyme, Russia) using oligo-(dT) 18 primer (Syntol, Russia) at $37^{\circ} \mathrm{C}$ for 75 minutes. For inactivation of the enzyme, reactions were heated to $70^{\circ} \mathrm{C} .2 \mu \mathrm{l}$ of cDNA mixture were used as a template for PCR with primers dirBam (5'- ATTAGGATCCGGATATGGAATGACCGAGGCAG-3') and revBam, (5' GATTGGATCCTTTCATGATCTGATCACCCCG-3'). Amplification parameters: hot start denaturation at $96^{\circ} \mathrm{C}$ for $3 \mathrm{~min}$, denaturation at $95^{\circ} \mathrm{C}$ for $45 \mathrm{sec}$, annealing at $62^{\circ} \mathrm{C}(n p t I I), 58^{\circ} \mathrm{C}$ (in case of $\operatorname{VirB}$ gene) or $59^{\circ} \mathrm{C}$ ( $4 C L$ construction) for $45 \mathrm{sec} ; 1 \mathrm{~min}$ elongation at $72^{\circ} \mathrm{C} ; 31$ cycles. Reactions were set up in $200 \mu \mathrm{l}$ thin-walled tubes (QSP) in the MJ MiniTM Gradient Thermal Cycler (Bio-Rad, USA). To control the RNA contamination by residual genome DNA, PCR was carried out with the RNA preparation from each clone without treating with the reverse transcriptase. Actin gene with primers Act-up (5'TATGCCCTCCCACATGCCAT-3') and Act-low (5' CATCTGCTGGAAGGTGCTGA-3') was used as a reference to normalize the target $4 C L$ gene signal. The expected PCR product size was $741 \mathrm{bp}$.

\section{5 .RT-PCR Analysis}

Levels of the gene expression were assessed by using cDNA preparations obtained with the real-time PCR. An intercalating dye SYBR Green was used as a fluorophore for detecting the reaction products. Amplification was carried out in the ANK 32 apparatus (Syntol, Russia) with the RT-PCR reaction mixture M-427 (Syntol, Russia). Primers used in the RT-PCR experiments are listed in Table 1. Amplification conditions: denaturation at $95^{\circ} \mathrm{C}$ for $5 \mathrm{~min}$, then 45 cycles (primer alnnealing and elongation at $60^{\circ} \mathrm{C}$ for 40 $\mathrm{sec}$, denaturation at $95^{\circ} \mathrm{C}$ for $15 \mathrm{sec}$ )

Specificity of amplification was estimated using melting curves. As a reference gene, ubiquitin was used. Expression levels of target genes in the transgenic plants were normalized to expression levels of the same genes in the non-transgenic control plants. Gene expression levels were calculated according to the $2^{-\Delta \Delta \mathrm{Ct}}$ method [20].

Table. 1. Primers used in the RT-PCR

\begin{tabular}{|c|c|}
\hline Primer name & Nucleotide sequence \\
\hline Act-up & 5'-TATGCCCTCCCACATGCCAT-3' \\
\hline Act-low & 5'-CATCTGCTGGAAGGTGCTGA-3' \\
\hline 4CL1 & 5'-CTTTGTTAATAGCCCATCCAG-3' \\
\hline 4CL2 & 5'-TGATTTCACAGCAAATGCAAC-3' \\
\hline CAD6-fw & 5'-GGTAGGAAGCAAAGTTGAAAAGTTC-3' \\
\hline CAD6-rew & 5'-TAGCCTCCGTACGTGGTGGTTCCAT -3' \\
\hline CCoAOMT1-fw & 5'-GTACCTCACATACTTCCTCATTGGT-3' \\
\hline CCoAOMT1-rew & 5'-TGGAAGTTTTGATTCATCTTTG -3' \\
\hline CCR1-fw & 5'-AGTTTTCCATACTGCTTCTGTC-3' \\
\hline CCR1-rew & 5'-ACAACATCAGGGCTCCTATTGGGGT-3' \\
\hline
\end{tabular}

\section{6 .Analysis of Transgenic Plant in Vitro Rooting}

During the experiment in vitro rooting was dissected in 15 apical explants of non-transgenic control and each of the transgenic lines. Rooting analysis was carried out in the WPM medium containing $1 \mathrm{mg} / \mathrm{l} \mathrm{MS}$ vitamins, $30 \mathrm{mg} / \mathrm{l}$ kanamycin. For each explant, root number, total root length and number of plants rooted by 6,9 and 12 days of experiment were calculated. The experiment was repeated four times.

\subsection{Analysis of Root Morphology in Plants Grown Un- der Semi-Natural Conditions}

Seven months old plants grown for 3 months in a greenhouse and for 4 months under semi-natural conditions were harvested for analyzing the wood composition and root system morphology. Root system was carefully washed without damaging the feeding roots. Roots were dried at room temperature and weighed. Then, coarse and fine roots were separated and each group was weighed individually. Five root systems were used for each line and the control.

Determining lignin and cellulose content was performed using previously described method [10].

Statistical treatment of data was carried out using the KruskalWallis test [21]

\section{Results}

Upon agrobacterium-mediated transformation, 14 transgenic aspen plant lines were obtained [10] in which incorporation of the target 4CL construction has occurred. Decrease in expression levels of the 4CL gene was confirmed with RT-PCR method. Maximum reduction was observed in two lines, PtXIII4CL2c and PtXVI4CL9a. Chemical analysis has shown that the lignin content was $23 \%$ and $11 \%$ reduced in the wood of greenhouse-grown plants of these lines by 6 months of age [10]. During in vitro cultivation of transformants, greater number of adventitious roots was observed in clones with reduced expression of the 4CL gene. For 
this reason we studied rooting efficiency in transgenic lines in vitro and under semi-natural conditions.

Table 2 represents results of dissection of rhizogenesis in microshoots of lines Pt, PtXIII4CL2c, and PtXVI4CL9a by 6, 9, and 12 days of cultivation in vitro.

Table 2. In vitro rhizogenesis of the transgenic aspen plants.

\begin{tabular}{|c|c|c|c|}
\hline Parameter & $\mathrm{Pt}$ & PtXIII4CL2c & PtXVI4CL9a \\
\hline \multicolumn{4}{|c|}{6 days after rooting } \\
\hline $\begin{array}{c}\text { Mean number of roots per } \\
\text { plant }\end{array}$ & $\begin{array}{c}1.5 \pm \\
0,1 \\
\end{array}$ & $1.8 \pm 0.04$ & $1.7 \pm 0.06$ \\
\hline $\begin{array}{l}\text { Total root length of a single } \\
\text { plant, mm }\end{array}$ & $\begin{array}{l}3 \pm \\
0.35\end{array}$ & $3.52 \pm 0.3$ & $3.4 \pm 0.2$ \\
\hline Rooting frequency, $\%$ & 63.4 & 83.4 & 70 \\
\hline \multicolumn{4}{|c|}{9 days after rooting } \\
\hline $\begin{array}{c}\text { Mean number of roots per } \\
\text { plant }\end{array}$ & $\begin{array}{c}2.3 \pm \\
0.1 \\
\end{array}$ & $2.9 \pm 0.1$ & $2.5 \pm 0.11$ \\
\hline $\begin{array}{l}\text { Total root length of a single } \\
\text { plant, } \mathrm{mm}\end{array}$ & $\begin{array}{c}21.6 \pm \\
1.1\end{array}$ & $25.4 \pm 0.7$ & $21.6 \pm 0.5$ \\
\hline Rooting frequency, $\%$ & 95.6 & 93.5 & 82.2 \\
\hline \multicolumn{4}{|c|}{12 days after rooting } \\
\hline $\begin{array}{c}\text { Mean number of roots per } \\
\text { plant }\end{array}$ & $\begin{array}{c}2.5 \pm \\
0.2 \\
\end{array}$ & $2.9 \pm 0.17$ & $3 \pm 0.12$ \\
\hline $\begin{array}{c}\text { Total root length of a single } \\
\text { plant, mm }\end{array}$ & $\begin{array}{c}44.7 \pm \\
3.1\end{array}$ & $40 \pm 1.7$ & $50 \pm 1.1$ \\
\hline Rooting frequency, $\%$ & 98 & 98.4 & 100 \\
\hline
\end{tabular}

Mean values of four independent experiments \pm SEM (Standard Error mines) are given

One may see that transgenic line plants rapidly form larger number of adventitious roots (1.8 and 1.7 respectively, whereas 1.5 roots per shoot are typically formed in the control). Total root length in the control was $3 \mathrm{~mm}$, whereas it was $3.52 \mathrm{~mm}$ and 3.4 $\mathrm{mm}$ in these lines of transgenic plants. Portion of rooted plants for the PtXIII4CL2c clone was 20\% larger than in the control.

By the day 9 of the experiment, the mean number of roots formed by the PtXIII4CL2c transgenic plants was also higher that in the control, but the root length in all transgenic plants was equal to that in the control (Fig.1). Portion of rooted plants in case of the PtXIII4CL2c clone was close to the control value, whereas it was $10 \%$ smaller in case of the PtXVI4CL9a clone.

By the day 12 of the experiment, the mean number of roots in lines PtXIII4CL2c and PtXVI4CL9a was higher than in the control, whereas total length of their roots was equal to that of the control plants. Portion of rooted plants for all clones was close to $100 \%$. In the control, almost all plants had lateral roots, whereas in case of transgenic lines such events were sporadic.

Thus, under the in vitro conditions, induced formation of adventitious roots and reduced formation of lateral roots are observed.

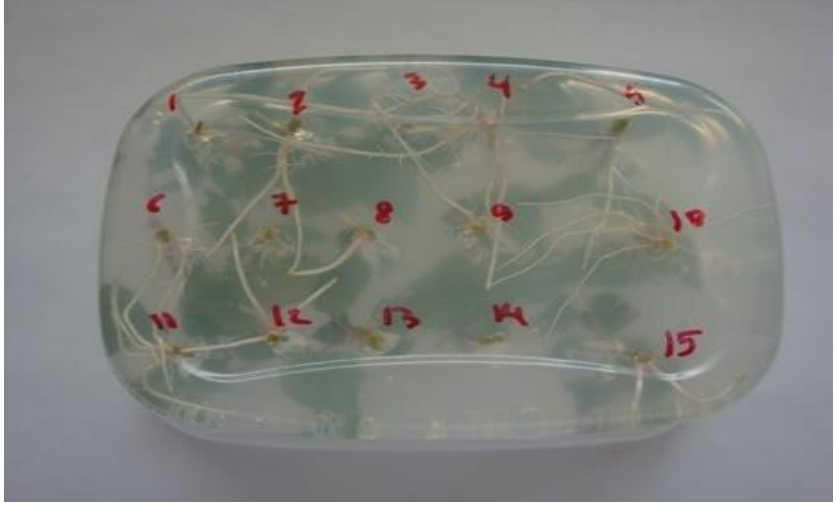

a)

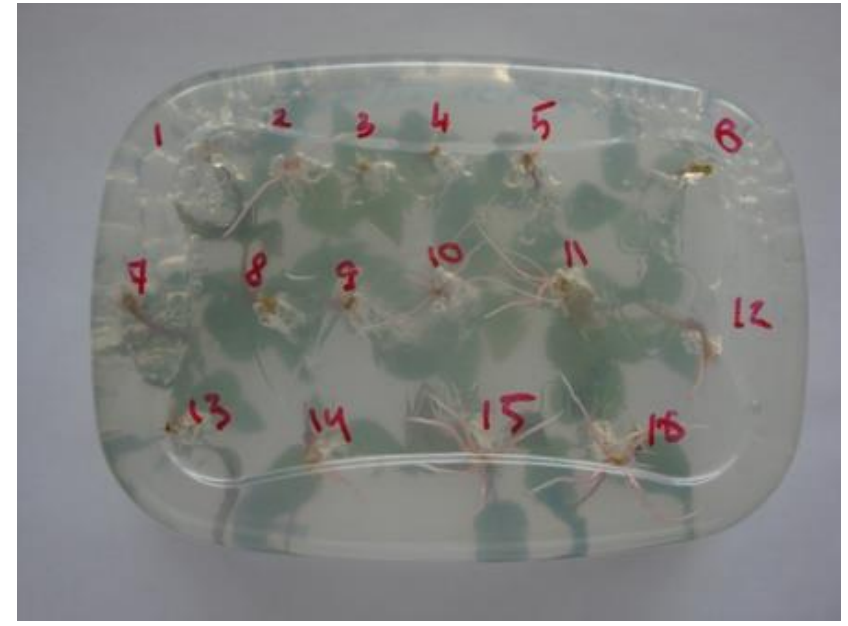

b)

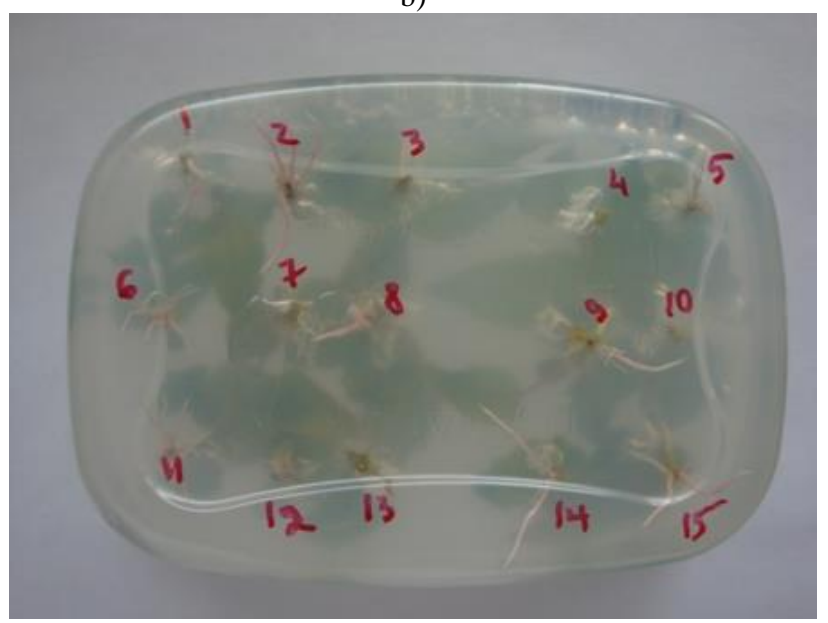

c)

Fig. 1. In vitro rooting of aspen microshoots at the day 9 of the experiment. a) control Pt plants, b) PtXIII4CL2c clone, c) PtXVI4CL9a clone.

Micro-plants of the transgenic lines and the control were adapted to the protected soil conditions and then to the open ground. Young leaves were collected from the plants grown under seminatural conditions. RNA was extracted and used for assessing expression levels of monolignol biosynthesis genes. As levels of native enzymes were assessed, parameters of the original genotype $\mathrm{Pt}$ were taken as 1 . As seen on the Fig. 2 (A), expression of the 4CL gene was reduced to 0.08 in the line PtXIII4CL2c and to 0.13 in the line PtXVI4CL9a. Under semi-natural conditions minimal expression levels were observed for the target gene. 

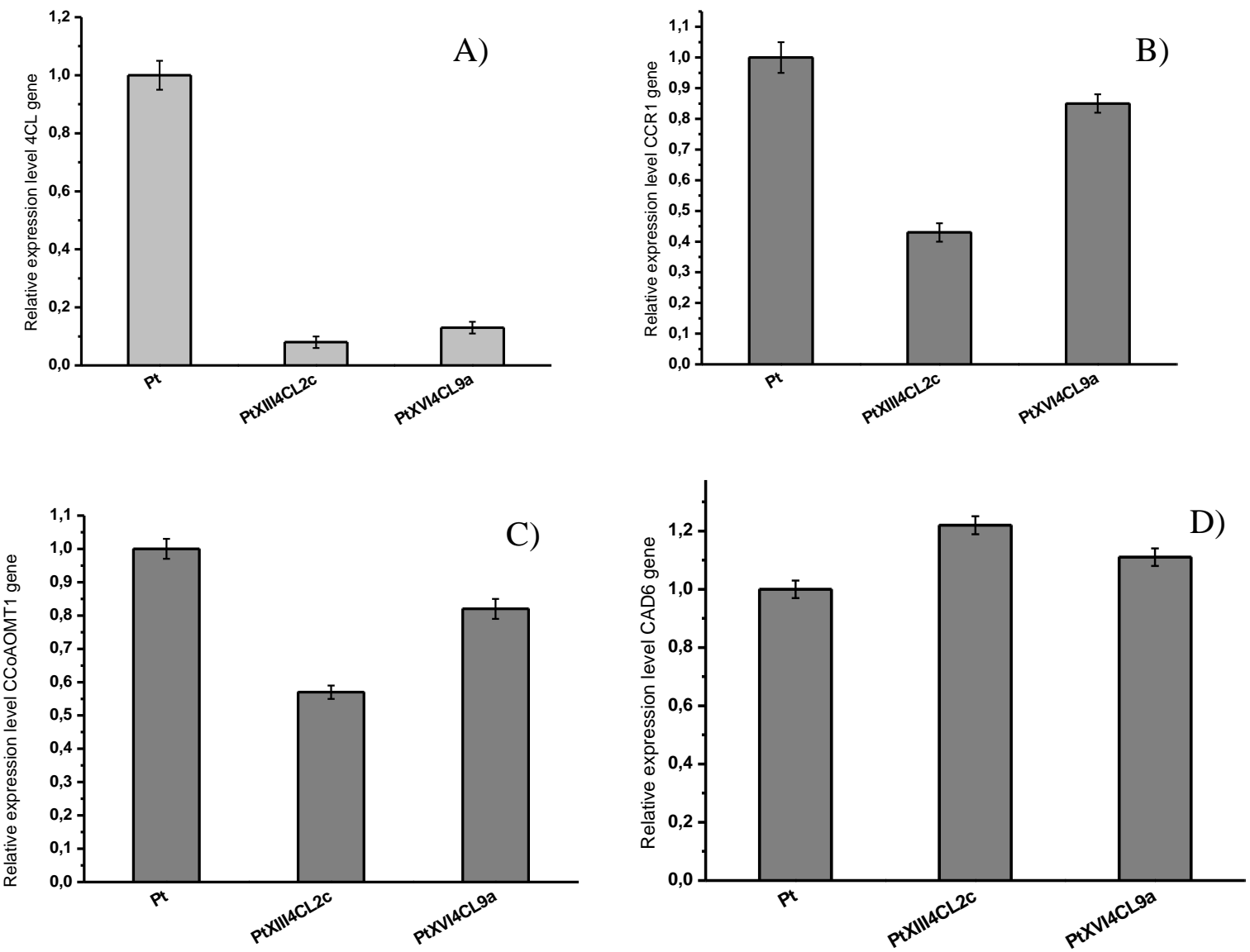

Fig. 2. RT-PCR analysis of expression of the native 4CL (A), CCR1 (B), CCoAOMT1 (C), CAD6 (D) gene in the seven months old transgenic aspen plants grown for three months in a greenhouse and four month under semi-natural conditions.

Expression of the monolignol biosynthesis genes has changed as follows: expression levels were decreased for genes CCR1 (Fig 2B) and CCoAOMT1 (Fig.2C) approximately by 50\% in the line PtXIII4CL2c and 20\% in PtXVI4CL9a transformants. Expression levels for the enzyme CAD6, which acts at final steps of monolignol biosynthesis was increased by $11 \%$ in the PtXVI4CL9a line and by $22 \%$ in PtXIII4CL2c line (Fig.2D).

Testing transgenic plants under open ground conditions often lead to decrease of parameters characterizing transformation due to powerful compensatory mechanisms in plant organism. This is why the lignin content different in plants grown under seminatural conditions and the ones grown in a greenhouse. As seen in the Table 3, the lignin content has decreased in the transgenic lines by $5.5 \%$ in the PtXIII4CL2c plants and by $11 \%$ in the PtXVI4CL9a plants. Portion of acid-soluble lignin is increased, whereas portion of acid-insoluble lignin is reduced (Table 3 ). In the PtXIII4CL2c line portion of acid-soluble lignin is $26 \%$ higher than in the control, portion of acid-insoluble lignin is reduced.

Table 3. Lignin and cellulose contents (\%) in the seven months old transgenic aspen plants (three months in a greenhouse and four months under seminatural conditions).

\begin{tabular}{|c|c|c|c|c|}
\hline Genotype & Total lignin & Acid-soluble lignin & Acid-insoluble lignin, Klason lignin \\
\hline Pt & $19.9 \pm 0.3$ & $1.9 \pm 0.3$ & $18 \pm 0.3$ & $42.95 \pm 0.3$ \\
\hline PtXIII4CL2c & $19 \pm 0.3$ & $2.4 \pm 0.3$ & $16.6 \pm 0.3$ & $43.7 \pm 0.3$ \\
\hline PtXVI4CL9a & $17.7 \pm 0.3$ & $2 \pm 0.3$ & $15.7 \pm 0.3$ & $46.5 \pm 0.3$ \\
\hline
\end{tabular}

Portion of acid-insoluble lignin in wood of the PtXVI4CL9a line is $15 \%$ reduced as compared to the original genotype. Similar tendency is also observed in greenhouse plants [10].

The most important parameters of productivity are height and stem diameter. We have measured height and stem diameter in the 7 months old transgenic plants and the control. It turned out that the transgenic PtXIII4CL2c plants with reduced lignin content are $40 \%$ lower than the control plants, whereas plants of the PtXVI4CL9a line are 45\% higher (Fig. 3). All results are statistically significant.

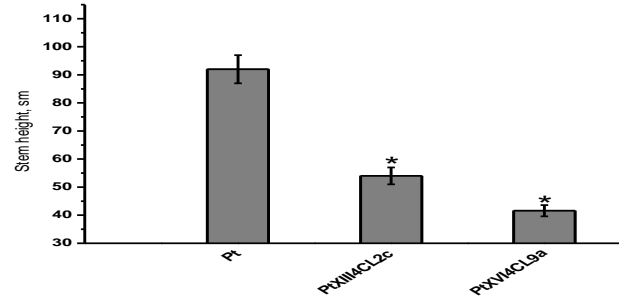

Fig. 3. Stem height in the seven months old plants grown for three months in a greenhouse and four month under semi-natural conditions. 30 plants sampling for each clone. Differences are significant with respect to the control $(\mathrm{Pt}), \mathrm{p}<0.01$. (Kruskal-Wallis test).

Stem diameter in transgenic plants was smaller than that in the control plants (Fig. 4). At the 7 months age stem diameter in 
plants of the PtXIII4CL2c line was $18 \%$ smaller than in the control. More significant difference was observed in the PtXVI4CL9a plants. In this case stem diameter was $27 \%$ smaller as compared to the control. Диаметр ствола трансформантов этой линии меньше контрольных показателей на 27\%. All results of measuring the diameter are statistically significant.

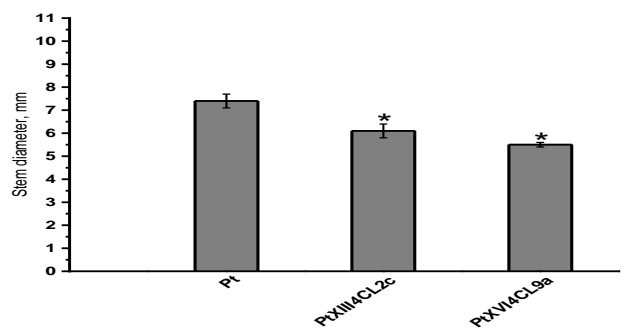

Fig. 4. Stem diameter in the seven months old plants grown for three months in a greenhouse and four month under semi-natural conditions. 30 plants sampling for each clone. Differences are significant with respect to the control $(\mathrm{Pt}), \mathrm{p}<0.01$. (Kruskal-Wallis test)

Analysis of the morphology of root system has shown its weight is significantly decreased in the transgenic plants as compared to the control. As compared to the control, total weight of dry root system of the 7 months old plants was 35\% lower for PtXIII4CL2c line and 53\% lower for the PtXVI4CL9a line (Table. 4).

Table 4. Studying the weight of roots in the seven months old transgenic plants grown for three months in a greenhouse and four months under semi-natural conditions

\begin{tabular}{|c|c|c|c|c|}
\hline Genotype & $\begin{array}{c}\text { Total root } \\
\text { weight, g }\end{array}$ & $\begin{array}{c}\text { Coarse root } \\
\text { weight, g }\end{array}$ & $\begin{array}{c}\text { Fine root } \\
\text { weight, g }\end{array}$ & $\begin{array}{c}\text { Coarse:fine } \\
\text { root ratio }\end{array}$ \\
\hline & \multicolumn{5}{|c|}{6 months } \\
\hline Pt & $22.6 \pm 1.1$ & $11.3 \pm 0.4$ & $10.08 \pm 0.1$ & 1.04 \\
\hline PtXIII4CL2c & $14.8 \pm 0.7 *$ & $9.9 \pm 0.4 *$ & $5.7 \pm 0.1 *$ & 1.7 \\
\hline PtXVI4CL9a & $10.6 \pm$ & $6.4 \pm 0.08 *$ & $3.6 \pm 0.04 *$ & 1.8 \\
& $0.08 *$ & & & \\
\hline
\end{tabular}

Significant difference with respect to the non-transgenic control, $\mathrm{p}$ $<0.01$ (Kruskal-Wallis test). Mean values of measurements of five plants \pm SEM (Standard Error mines) are given. * - values significantly different from control.

Inhibition of growth of aboveground organs was associated with the reduction of root system. Weight of feeding and conductive roots in each transformant was lower than in the control. Significant decrease in weight of fine roots was observed: by $50 \%$ for the PtXIII4CL2c line and by $70 \%$ for the PtXVI4CL9a line as compared to the control. The coarse:fine root ratio in the control plants is approximately 1 , whereas in the lines under study it is 1.7-1.8 (Table 4). Thus, in addition to the growth inhibition, the transgenic plants feature reduced root system. At that, conductive roots prevail over feeding ones.

\section{Discussion}

Alteration of physiology and morphology in plants caused by modification of plants genome affect numerous organ systems. On an example of plants with reduced expression of the 4CL gene one may see changes in content and composition of lignin in wood, development of brown stem coloration, and decrease in plant height [1-13]. Researchers that achieved reduced lignin content using genetic engineering often observe development of brown coloration of xylem, impaired formation of vascular system, changes of growth parameters [22]. For instance, stunted growth and delayed root formation were observed upon inhibition of genes PAL2 (phenylalanine ammonia-lyase) in tobacco plants and PAL1 in Salvia miltiorrhiza, [23-24]. Reduced expression of the CCR gene in tobacco plants are accompanied by growth defects, xylem decomposition and development of orange-brown coloring [25].
Xylem decomposition and dwarfing phenotype are observed In Arabidopsis thaliana plants mutant for the cinnamate-3hydroxylase $(\mathrm{C} 3 \mathrm{H})$ gene REF8 [26]. This is a main list of morphological and phenotypic changes, which are currently demonstrated for plants with altered expression of monolignol biosynthesis genes. We have discovered changes of the root system phenotype and reduced lignin content in transgenic aspen lines with minimal expression levels of the 4CL gene.

Reduced by $5.5 \%$ and $10 \%$ lignin content in the PtXIII4CL2c and PtXVI4CL9a plants, grown under semi-natural conditions (three month in a greenhouse and four months in the open ground) agrees with the results of Voelker and colleagues during dissecting poplars with 4CL gene inhibited using the anti-sense RNA approach $[8,9]$. Wood of poplars grown in open ground lignin content was reduced by $10 \%$ [8-9]. Similar results for lignin content were obtained by Chinese researchers, who partially repressed 4CL gene expression in the poplar Populus tomentosa Carr. using the RNAi method [27]. Lignin content was reduced by $11.67 \%$ and $4.38 \%$ in plants vegetated in open ground for half a year. Thus, inhibiting expression of the 4CL gene in plants of genus Populus leads to decrease in lignin content in general by $10 \%$ upon growing in open ground. Results obtained under our conditions on lignin content in wood of the transgenic plants correspond to data of other researchers, who performed experiments in open ground.

We have observed decrease in height (by 40-45\%) and stem diameter (by 18-34\%) in plants of PtXIII4CL2c and PtXVI4CL9a lines with reduced lignin content. One may conclude that these plants demonstrate dwarfing phenotype during cultivation in open ground. Plants of the PtXIII4CL2c line grown in a greenhouse were $20 \%$ lower than the control [10]. Open ground conditions reduced humidity, temperature fluctuations, action of solar radiation, and other abiotic factors cause development of stress response in plants, which affects growth parameters in clones [28]. Decrease in height of plants with inhibition of the lignin biosynthesis genes is commonly attributed to reduced content of lignin, which is required for providing rigidity of a plant secondary cell wall and protective properties [29]. Looking at the lignin biosynthesis scheme one may see that phenylalanine is used for synthesis of monolignol precursors and monolignols with the participation of enzymes PAL, C4H, C3H, 4CL, HCT ( $p$-hydroxycinnamoylCoA transferase), CCoAOMT, CCR. Inhibition of expression of genes of these enzymes typically results in growth defects in mutant and transgenic plants [22]. In the plants we obtained, significant decrease in expression levels of 4CL, CCR, and CCoAOMT was observed, which might lead to reduced height in the transgenic plants. In the PtXIII4CL2c and PtXVI4CL9a plants expression levels of the 4CL gene was reduced to 0.08 and 0.13 , respectively, relatively to the control parameters. These values are lower than in plants grown in a greenhouse (28\%) [10]. One may conclude that decreased expression levels of the 4CL gene in plants grown under semi-natural conditions correlates with their reduced height. We also demonstrated similar tendency for plants grown in a greenhouse [10].

A problem of change in the plant height is addressed by researchers of transgenic plants with altered expression levels of lignin biosynthesis enzymes. However, there are no data regarding changes of the root phenotype in such lines.

In the present study we discovered induced formation of adventitious roots and reduced formation of lateral roots in vitro in plants of the lines PtXIII4CL2c and PtXVI4CL9a (Table 2). Plants with reduced by 5 and $10 \%$ lignin content grown under semi-natural conditions (three months in a greenhouse and four months in an open ground) at the age of 7 months demonstrate decrease in total root mass by $35 \%$ and $53 \%$ and altered coarse:fine root ratio as compared to the control genotype. It is known that decrease in expression levels of the 4CL gene results in impaired formation of vascular systems in the plant stem [8-9,11]. Apparently, these plants undergo phenotypic changes not only in the stem, but also in roots. A modified root system cannot sufficiently supply plant 
with water and minerals, which are required for normal growth. This contributes to reduction of height of transformants and formation of dwarfing phenotype $[16,17]$.

\section{Conclusion}

Considering the above mentioned one may assume that alteration of the expression levels of the 4CL gene in transgenic aspen plants grown under semi-natural conditions could cause changes in lignin content and composition, decrease in height and stem diameter, and also impairment of vascular systems not only in stem, but also in roots. Along with this, the root phenotype is changed. Manifestations of such changes are intensification of adventitious rooting and impairment of formation of lateral roots in transgenic plants in vitro. When cultivated in semi-natural conditions, these disorders lead to thickening of the main conductive roots and deterioration of the formation of feeding roots, which is manifested in the change in the mass ratios of feeding and conducting roots.

\section{Acknowledgements}

This research was carried out within the state program of The Federal Agency of Scientific Organizations of Russian Federation (theme "Modification of the wood structure and the phenotype of aspen plants by superexpression of xyloglucanes gene sp-Xeg and inhibition of expression 4-Coumarate:CoA Ligase gene" No. 01201352438)

\section{References}

[1] Pilate G, Guiney E, Holt K, Petit-Conil M, Lapierre C, Leplé JC, Pollet B, Mila I, Webster EA, Marstorp HG, et al. Field and pulping performances of transgenic trees with altered lignification.//Nat $\mathrm{Bi}$ otechnol. 2002. V. 20. P. 607-612.

[2] Anterola AM, Lewis NC. Trends in lignin modification: a comprehensive analysis of the effects of genetic manipulation/mutations on lignification and vascular integrity // Phytochemistry. 2002. V. 61. №3. P 221-294.

[3] Vanholme R., Storme V., Vanholme V., Sundin L., Christensen J.-H., Goeminne G., Halpin C., Rohde A., Morreel K., and Boerjana W. A systems biology view of responses to lignin biosynthesis perturbations in Arabidopsis. // The Plant Cell. 2012. V. 24. P. 3506-3529.

[4] Wagner A., Donaldson L., Kim H., Phillips L., Flint H., Steward D. Torr K., Koch G., Schmitt U.,Ralph J. Suppression of 4-CoumarateCoA ligase in the coniferous gymnosperm Pinus radiata // Plant Physiol. 2009. V. 149. P. 370-383.

[5] Hu W-J., Kawaoka A., Tsai C-J., Lung J., Osakabe K., Ebinuma H. Chiang V. L. // Compartmentalized expression of two structurally and functionally distinct 4-coumarate: CoA ligase genes in aspen (Populus tremuloides) // Plant Biology. 1998. V. 95. P. 5407 - 5412.

[6] Hu W-J., Harding S. A., Lung J., Popko J. L., Ralph J., Stokke D. D., Tsai C-J., Chiang V. L. Repression of lignin biosynthesis promotes cellulose accumulation and growth in transgenic trees // Nature biotechnology. 1999. V. 17. P. $808-812$.

[7] Voelker S. L., Lachenbruch B., Meinzer F. C., Jourdes M., Ki C., Patten A. M., Davin L. B., Lewis N. G., Tuskan G. A., Gunter L., Decker S. R., Selig M. J., Sykes R., Himmel M. E., Kitin P., Shevchenko O., Strauss S. H. Antisense Down-Regulation of 4CL Expression Alters Lignification, Tree Growth, and Saccharification Potential of Field-Grown Poplar // Plant Physiology. 2010. V. 154 P. $874-886$.

[8] Voelker S. L., Lachenbruch B., Meinzer F. C., Kitin P., Strauss S. Transgenic poplars with reduced lignin show impared xylem conductivity, growth efficiency and surval. // Plant Cell Environ. 2011 V. 34. P. 655-68.

[9] Li L., Zhou Y., Cheng X., Sun J., Marita J. M., Ralph J., Chiang V. $L$. Combinatorial modification of multiple lignin traits in trees through multigene cotransformation // PNAS. 2003. V. 100. P $4939-4944$.

[10] Kovalitskaya Yu. , Dayanova L., Azarova A. and Shestibratov K. RNA Interference-Mediated Down-Regulation of 4- Coumarate: Coenzyme A Ligase in Populus Tremula Alters Lignification and
Plant Growth // International journal of environmental \& science education. 2016. V. 11. № 18. P. 12259-12271.

[11] Leplé JC, Dauwe $R$, Morreel K, Storme V, Lapierre C, Pollet $B$, Naumann A, Kang KY, Kim H, Ruel K, Lefèbvre A, Joseleau $J P$, Grima-Pettenati J, De Rycke R, Andersson-Gunnerås $S$, Erban A, Fehrle I, Petit-Conil M, Kopka J, Polle A, Messens E, Sundberg $B$, Mansfield SD. Downregulation of cinnamoyl-coenzyme A reductase in poplar: multiple-level phenotyping reveals effects on cell wall polymer metabolism and structure. // Plant Cell. 2007. V 19. № 11.P:3669-91.

[12] Kajita, S., Katayama, Y., and Omori, S. Alterations in the biosynthesis of lignin in transgenic plants with chimeric genes for 4 coumarate: coenzyme A ligase // Plant Cell Physiol. 1996. V. 37. P. 957-965.

[13] Kajita, S., Hishiyama, S., Tomimura, Y., Katayama, Y., and Omori, $S$. Structural characterization of modified lignin in transgenic tobacco plants in which the activity of 4-coumarate: coenzyme A ligase is depressed // Plant Physiol. 1997. V. 114. P. 871- 879.

[14] Simon J.T., Lewis L., Lopes-Gonzalez G. et all. Methods to estimate aboveground wood productivity from long-term forest inventory plots // Forest Ecology and Management. 2014. V. 320. P. 30-38.

[15] Rahaman M., Chen D., Gillani Z., Klukas Ch., Chen M. Advanced phenotyping and phenotype data analysis for the study of plant growth and development // Front Plant Sci. 2017. V. 8: P. 1617.

[16] Jung J.K.H and McCouch S. Getting to the roots of it: Genetic and hormonal control of root architecture // Front Plant Sci. 2013 V. 4 : P.186.

[17] Peukert J.M., Succurro A., Koprivova A. and Kopriva S. The Role of Soil Microorganisms in Plant Mineral Nutrition-Current Knowledge and Future Directions Richard // Front Plant Sci. 2017. V. 8: P. 1617.

[18] Lloyd, G.; McCown, B.,Commercially-feasible micropropagation of mountain laurel, Kalmia latifolia, by use of shoot-tip culture // Combined Proceedings, International Plant Propagators' Society. 1981. - V. 30. - P. 421-427.

[19] Murashige T., Skoog F. A Revised Medium for Rapid Growth and Bioassays with Tobacco Cultures. // Physiol. Plant. 1962. V. 15. P. 473-497.

[20] Livak KJ, Schmittgen TD. Analysis of relative gene expression data using real-time quantitative PCR and the 2(-Delta Delta C(T)) // Method. Methods. Vol. 25. San Diego, CA: 2001 pp. 402-408.

[21] Kruskal W. H., Wallis W. A. Use of ranks in one-criterion variance analysis. // Journal of the American Statistical Association. 1952. V. 47. № 260. P. 583-621.

[22] Jinmi Yoon, Heebak Choil and Gynheung An. Roles of lignin biosynthesis and regulatory genes in plant development // Journal of Integrative Plant Biology. 2015. V. 57. № 11. P. 902-912.

[23] Elkind $Y$, Edwards $R$, Mavandad M, Hedrick SA, Ribak O, Dixon $R A$, Lamb CJ Abnormal plant development and down-regulation of phenylpropanoid biosynthesis in transgenic tobacco containing a heterologous phenylalanine ammonia-lyase gene. // Proc Natl Acad Sci USA 1990. V. 87. P. 9057-9061.

[24] Song J, Wang Z . RNAi-mediated suppression of the phenylalanine ammonia-lyase gene in Salvia miltiorrhiza causes abnormal phenotypes and a reduction in rosmarinic acid biosynthesis. // J Plant Res. 2011. V. 124. P. 193-192.

[25] Piquemal J, Lapierre C, Myton K, O'Connell A, Schuch W, GrimaPettenati J, Boudet A. Downregulation of cinnamoyl CoA reductase induces significant changes of lignin profiles in transgenic tobacco plants. // Plant J. 1998. V. 13. P. 71-83.

[26] Franke R, Hemm MR, Denault JW, Ruegger MO, Humphreys JM, Chapple C (2002) Changes in secondary metabolism and deposition of an unusual lignin in the ref8 mutant of Arabidopsis. Plant J 30: $47-59$

[27] Tian XM, Xie J, Zhao YL, Lu H, Liu SC, Qu L, Li JM, Gai Y, Jiang $X N$. Sense-, antisense- and RNAi-4CL1 regulate soluble phenolic acids, cell wall components and growth in transgenic Populus tomentosa Carr. // Plant Physiology and Biochemistry. 2013. V. 65. P. 111-119.

[28] Meng-Zhu Lu and Jian-Jun Hu. A brief overview of field testing and commercial application of transgenic trees in China // BMC Proc. 2011. V.5. P. 063.

[29] Xu Li, Nicholas D. Bonawitz, Jing-Ke Weng, 1 and Clint Chapple. The Growth Reduction Associated with Repressed Lignin Biosynthesis in Arabidopsis thaliana Is Independent of Flavonoids // The Plant Cell. 2010. V. 22. P. 1620-1632. 